Article

\title{
Dexamethasone Induces the Expression and Function of Tryptophan-2-3-Dioxygenase in SK-MEL-28 Melanoma Cells
}

\author{
Marta Cecchi ${ }^{1}$ (D) , Sara Paccosi ${ }^{1}$ (D) Angela Silvano ${ }^{1}$, Ali Hussein Eid ${ }^{2,3, *}$ and Astrid Parenti $^{1, *(D)}$ \\ 1 Department of Health Sciences, Clinical Pharmacology and Oncology Section, University of Florence, \\ Viale Pieraccini 6, 50139 Florence, Italy; marta.cecchi@unifi.it (M.C.); sara.paccosi@unifi.it (S.P.); \\ angela.silvano@unifi.it (A.S.) \\ 2 Department of Basic Medical Sciences, College of Medicine, QU Health, Qatar University, \\ Doha P.O. Box 2713, Qatar \\ 3 Biomedical and Pharmaceutical Research Unit, QU Health, Qatar University, Doha P.O. Box 2713, Qatar \\ * Correspondence: ali.eid@qu.edu.qa (A.H.E.); astrid.parenti@unifi.it (A.P.); Tel.: +974-4403-7893 (A.H.E.)
}

\section{check for}

updates

Citation: Cecchi, M.; Paccosi, S.; Silvano, A.; Eid, A.H.; Parenti, A. Dexamethasone Induces the Expression and Function of Tryptophan-2-3-Dioxygenase in SK-MEL-28 Melanoma Cells. Pharmaceuticals 2021, 14, 211. https://doi.org/10.3390/ ph14030211

Academic Editor: Vadim S. Pokrovsky

Received: 1 February 2021

Accepted: 28 February 2021

Published: 4 March 2021

Publisher's Note: MDPI stays neutral with regard to jurisdictional claims in published maps and institutional affiliations.

Copyright: (c) 2021 by the authors. Licensee MDPI, Basel, Switzerland. This article is an open access article distributed under the terms and conditions of the Creative Commons Attribution (CC BY) license (https:/ / creativecommons.org/licenses/by/ $4.0 /)$.

\begin{abstract}
Tryptophan-2,3-dioxygenase (TDO) is one of the key tryptophan-catabolizing enzymes with immunoregulatory properties in cancer. Contrary to expectation, clinical trials showed that inhibitors of the ubiquitously expressed enzyme, indoleamine-2,3-dioxygenase-1 (IDO1), do not provide benefits in melanoma patients. This prompted the hypothesis that TDO may be a more attractive target. Because the promoter of TDO harbors glucocorticoid response elements (GREs), we aimed to assess whether dexamethasone (dex), a commonly used glucocorticoid, modulates TDO expression by means of RT-PCR and immunofluorescence and function by assessing cell proliferation and migration as well as metalloproteinase activity. Our results show that, in SK-Mel-28 melanoma cells, dex up-regulated TDO and its downstream effector aryl hydrocarbon receptor (AHR) but not IDO1. Furthermore, dex stimulated cellular proliferation and migration and potentiated MMP2 activity. These effects were inhibited by the selective TDO inhibitor 680C91 and enhanced by IDO1 inhibitors. Taken together, our results demonstrate that the metastatic melanoma cell line SK-Mel-28 possesses a functional TDO which can also modulate cancer cell phenotype directly rather than through immune suppression. Thus, TDO appears to be a promising, tractable target in the management or the treatment of melanoma progression.
\end{abstract}

Keywords: SK-Mel-28; melanoma; tryptophan-2,3-dioxygenase; indoleamine-2,3-dioxygenase-1; dexamethasone; 680C91; epacadostat; migration; proliferation; MMP2

\section{Introduction}

L-tryptophan (Trp) is an essential amino acid that plays important roles in protein synthesis as well as the biosynthesis of melatonin, serotonin, and nicotinamide adenine dinucleotide $\left(\mathrm{NAD}^{+}\right)$[1]. The role of Trp catabolism in cancer biology has been receiving increased interest due to its implication in cancer immune evasion [2]. Indoleamine-2,3-dioxygenase-1 (IDO1) and tryptophan-2,3-dioxygenase (TDO) are the main enzymes within the first and rate-limiting step of the kynurenine pathway (KP) of Trp catabolism. Most Trp are catabolized by IDO1, which is ubiquitously expressed and can be induced by interferon gamma (IFN- $\gamma$ ) [3]. Interestingly, IDO1 has been widely demonstrated to possess immunosuppressive functions, which are established to correlate with poor survival in various cancer patients [2] (Figure 1).

Despite all efforts of early diagnosis, metastatic melanoma continues to have a poor prognosis [4]. In recent years, a better understanding of the role of the immune system in cancer has led to the approval of several immunotherapies using monoclonal antibodies against immune checkpoints, such as ipilimumab (anti CTLA-4) as well as nivolumab and pembrolizumab (anti PD-1) [4]. Unfortunately, only specific subgroups of patients responded to these immunotherapies, pointing out IDO1 as a further ideal candidate [3]. 
It was indeed reported that reduced serum tryptophan concentrations could be predictive markers for melanoma [5]. Although selective and potent IDO1 inhibitors have shown promising results in experimental models of cancer [6], their benefit in melanoma patients has not been completely elucidated. Indeed, in a phase 3 randomized, double blind study, ECHO-301/KEYNOTE-252, a selective IDO1 inhibitor, epacadostat $100 \mathrm{mg}$ twice daily, plus pembrolizumab did not improve progression-free survival or overall survival compared with placebo plus pembrolizumab in patients with unresectable or metastatic melanoma [7]. Due to the uncertain benefit of IDO1 inhibition as a strategy to enhance immune checkpoints activity, and since approximately $35 \%$ of tumor cancer cell lines express TDO [8], this enzyme became a very attractive target in cancer immunotherapy [9].

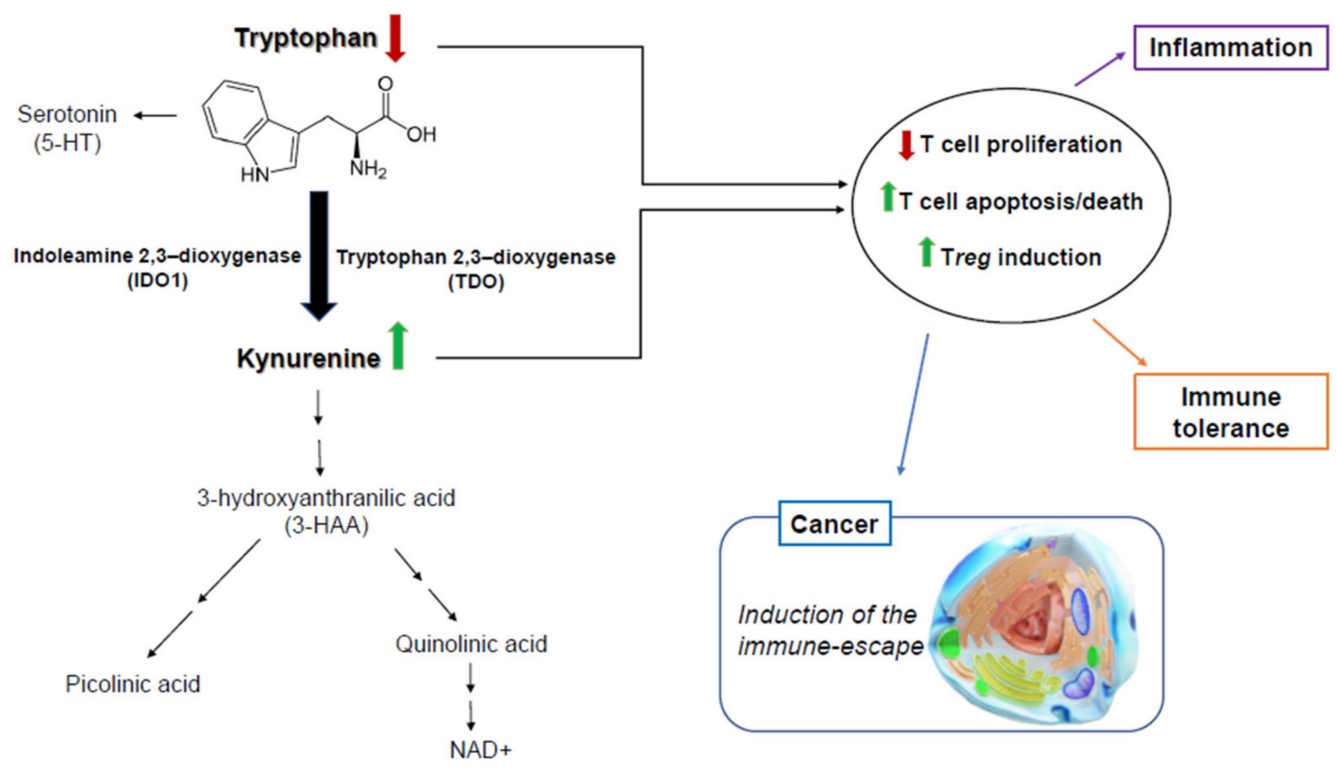

Figure 1. Tryptophan catabolism and kynurenine pathway. Indoleamine-2,3-dioxygenase (IDO1) and tryptophan-2,3dioxygenase (TDO) pathways control $\mathrm{T}$ cell and $\mathrm{T}_{\text {reg }}$ responses. IDO1—and TDO but to a lesser extent-are expressed on professional antigen presenting cells and tumor cells and are critical in immune regulation of cancers, infections, and inflammation.

TDO is physiologically expressed in the liver where it plays a critical role in regulating Trp levels. Following some stimuli, however, TDO's expression can be detected in several organs, including testis [10], placenta [11], and brain [12]. More recent studies have pointed out the relevance of TDO in some cancers, namely malignant glioma, melanoma, bladder cancer, and triple-negative breast carcinoma $[13,14]$. Indeed, TDO appears to be constitutively expressed in these cancer cells, and its upregulation has been intimately associated with the ability of tumor cells to evade immune surveillance [15]. Therefore, TDO may represent an attractive target, especially when IDO1 does not account for constitutive Trp catabolism $[8,16]$.

The glucocorticoid (GC) derivative dexamethasone (dex) is routinely used as a comedication in cancer therapy to ameliorate some side effects of chemotherapeutic agents [17,18]. In hematological malignancies, particularly in multiple myeloma, dex is part of all chemotherapy protocols, owing to its strong apoptosis-inducing effects [19]. However, GCs could also inhibit chemotherapy-induced tumor cell's apoptosis in in vitro and in vivo experimental models as well as in freshly obtained surgical specimens of some tumors, including melanoma [20].

The effects of dex on tumor cell growth remain inconclusive, likely due to the many factors involved, including dose and cell context $[21,22]$. Therefore, to clearly determine the clinical relevance of GCs, their effects on the malignant phenotype ought to be elucidated. Since TDO promotor possesses glucocorticoid response elements (GREs) [23], a role for 
TDO in tumor biology and progression has attracted attention, especially in the context of melanoma.

Based on these considerations, this study was undertaken to better characterize TDO/KP in SK-Mel-28, a human melanoma cell line. We previously demonstrated that TDO is constitutively expressed in these cells and that it directly regulates their proliferation [24]. However, the effect of dex on TDO expression and function remained unclear. Here, we seek to determine this role in order to better delineate glucocorticoid's effects on melanoma cells.

\section{Results}

\subsection{Dexamethasone Increased TDO and AHR Expression}

Since TDO promotor harbors GREs, we wished to determine the effect of dexamethasone (dex) on its expression in SK-Mel-28 cells. Our results show that dex indeed increases TDO mRNA (TDO2) expression in concentration (data not shown) and time-dependent manners. The maximal effect was observed after six hours of treatment with $25 \mu \mathrm{M}$ of dex (Figure 2A). Immunofluorescence analysis further confirmed the increase in protein levels of TDO in response to dex (Figure 2B).

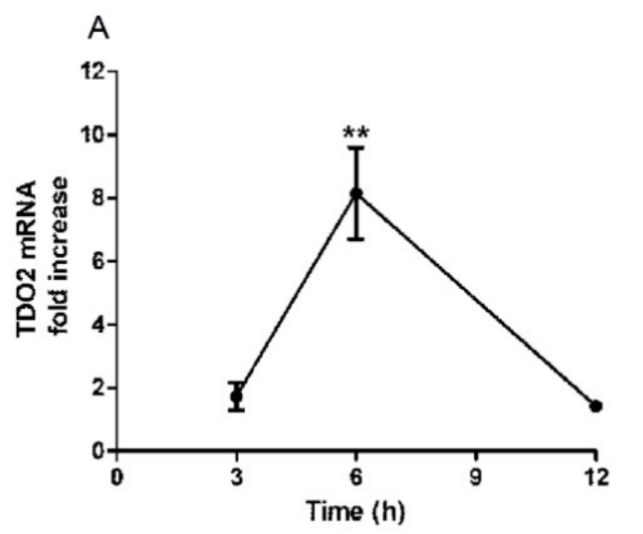

B

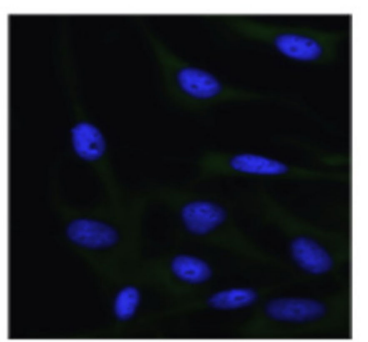

ctrl

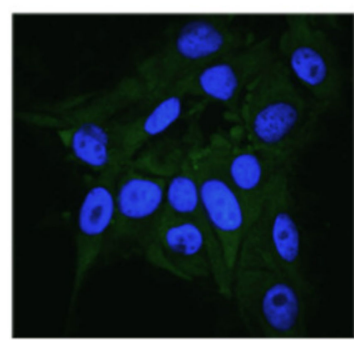

$\operatorname{dex} 6 \mathrm{~h}$

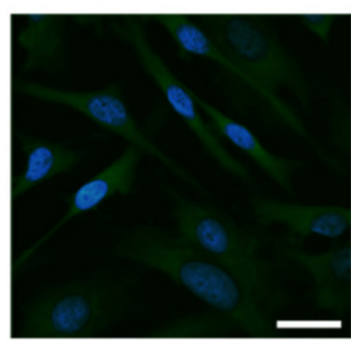

$\operatorname{dex} 24 \mathrm{~h}$

Figure 2. Dexamethasone (dex) increases mRNA and protein expression of TDO. (A) Cells were treated with dex (25 $\mu \mathrm{M})$ for different time points. RT-PCR shows time-dependent increase in mRNA of TDO2. Data are plotted as mean \pm SEM $(n=8$, ** $p<0.01$ vs. control). (B) Cells treated without (ctrl) or with $\operatorname{dex}(25 \mu \mathrm{M})$ for 6 or $24 \mathrm{~h}$, then subjected to immunofluorescence, TDO (green fluorescence), nuclei (blue). Representative photomicrographs at $40 \times$ magnification are shown. Scale bar $20 \mu \mathrm{m}$.

Given the influence of IDO1 on melanoma's malignant phenotype, we next aimed to determine its expression in SK-Mel-28. Electrophoresis of the amplified and purified target show that IFN- $\gamma(50 \mathrm{ng} / \mathrm{mL})$ but not dex $(25 \mu \mathrm{M})$ increased expression of IDO1 (Figure 3A). This was further confirmed by real-time PCR (Figure 3B) and immunofluorescence (Figure 3C). Interestingly, although IDO1 mRNA levels were almost undetectable, an IDO inhibitor, 1-MT, significantly enhanced dex-induced TDO2 upregulation (Figure 3D). This may suggest that SK-Mel-28 cells could use TDO as principal enzyme for the activation of the KP.

Among the downstream effectors of KP, the aryl hydrocarbon receptor (AHR) represents an important target. Our results show that treatment with dex upregulated mRNA and protein levels of AHR (Figure 4A,B). Interestingly, this effect was rapid, as it was significantly increased within $3 \mathrm{~h}$ of stimulation with dex (Figure $4 \mathrm{~A}$ ). This increase is not sustained since the level of AHR after $24 \mathrm{~h}$ of dex does not seem to cause an appreciable change over basal level (Figure $4 \mathrm{~B}$ ). This is likely due to the fact that dex accelerates both ligand-dependent and ligand independent AHR protein degradation in a GR-dependent manner [25]. 
A

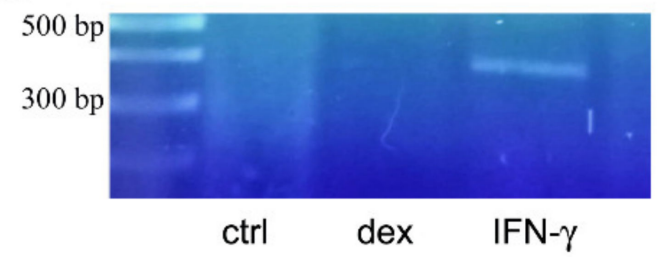

B
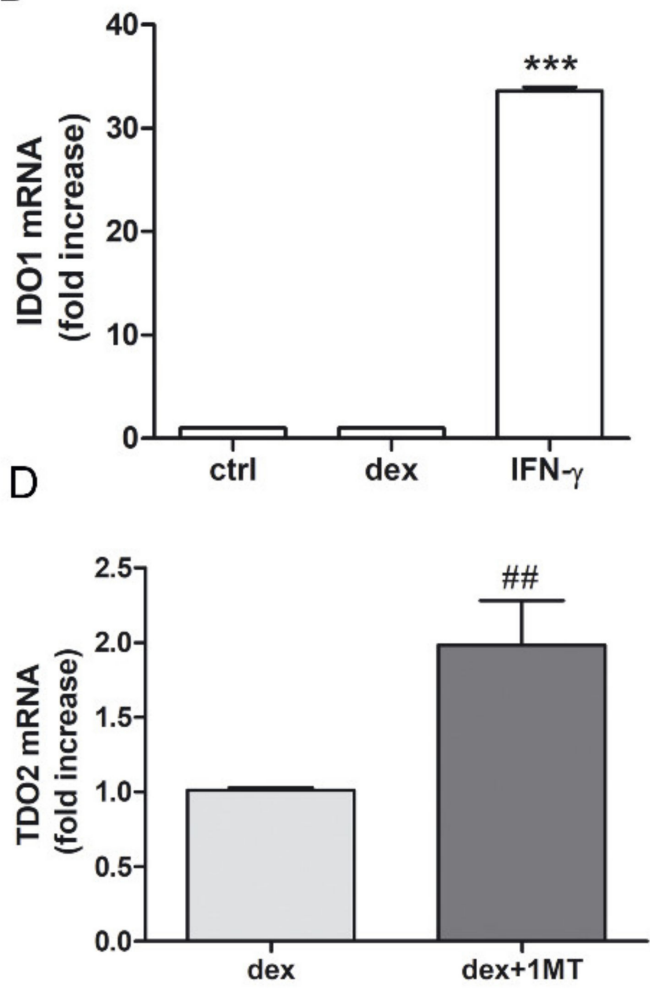

C

ctrl

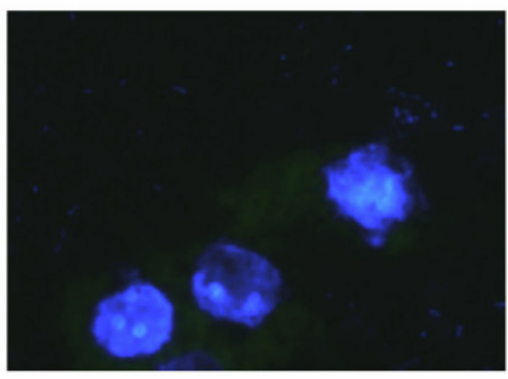

dex
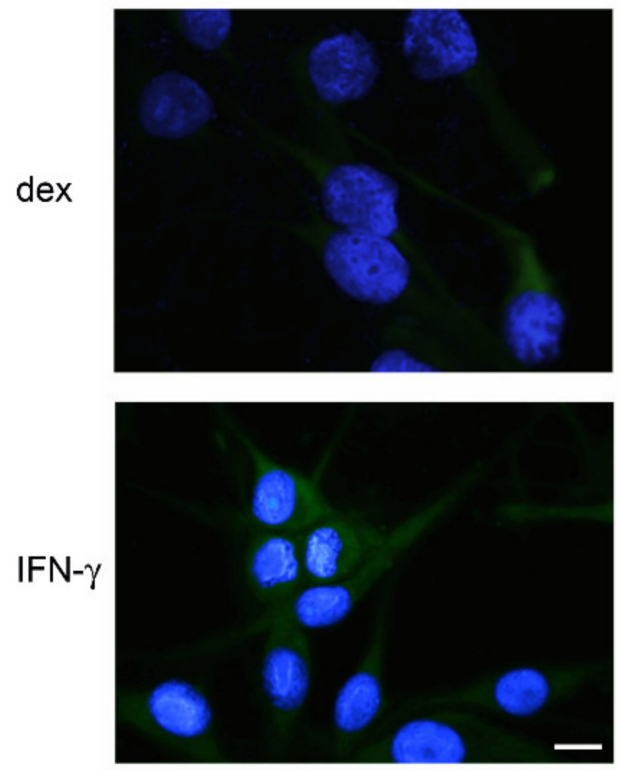

Figure 3. Modulation of IDO1 and TDO2 by interferon gamma (IFN- $\gamma$ ) or dex. (A) Cells were treated without (ctrl) or with $\operatorname{dex}(25 \mu \mathrm{M})$ or with IFN- $\gamma(50 \mathrm{ng} / \mathrm{mL})$ for $24 \mathrm{~h}$. Total RNA was then isolated, and RT-PCR-generated cDNA of IDO1 was subjected to agarose gel electrophoresis. (B) Cells were treated without (ctrl) or with dex $(25 \mu \mathrm{M})$ or with IFN- $\gamma(50 \mathrm{ng} / \mathrm{mL})$ for $24 \mathrm{~h}$. Total RNA was then isolated, and real time PCR was performed. Data represent mean \pm SEM, $\left(n=4 ;{ }^{* * *} p<0.001\right.$ vs. control unstimulated (ctrl) cells). (C) Cells were treated without (ctrl) or with dex $(25 \mu \mathrm{M})$ or with IFN- $\gamma(50 \mathrm{ng} / \mathrm{mL})$ for $24 \mathrm{~h}$, followed by immunofluorescence for IDO1 expression (IDO1: green; nuclei: blue). Representative photomicrographs at $40 \times$ magnification are shown. Scale bar $20 \mu \mathrm{m}$. (D) Cells were treated with dex $(25 \mu \mathrm{M})$ in the presence or absence of $40 \mu \mathrm{M}$ 1-MT, an IDO inhibitor. Real-time PCR results for TDO2 expression are shown. Data plotted represent mean $\pm \mathrm{SEM}$. Increase over dex effect ( $n=6$; \#\# $p<0.01$ vs. dex alone).

\subsection{Dexamethasone Stimulates SK-Mel-28 Proliferation via TDO and PI3K/Akt}

Because TDO is involved in the regulation of SK-Mel-28 growth [24], and since dex induced TDO up-regulation, we then wished to determine whether dex stimulates SKMel-28 proliferation via TDO. Our results show that dex significantly and concentrationdependently increased SK-Mel-28 proliferation (Figure 5A). The maximal effect was obtained with $25 \mu \mathrm{M}$, which caused a $48.4 \pm 9 \%$ increase in cell duplication compared to control unstimulated cells. Dex-promoted cell proliferation appears to be dependent on glucocorticoid receptors and on increased transcriptional activity, since it was abolished by the steroid receptor antagonist RU486 $(1 \mu \mathrm{M})$ and by actinomycin-D $(10 \mathrm{nM})$, a DNAdependent RNA synthesis inhibitor (Figure 5B). 


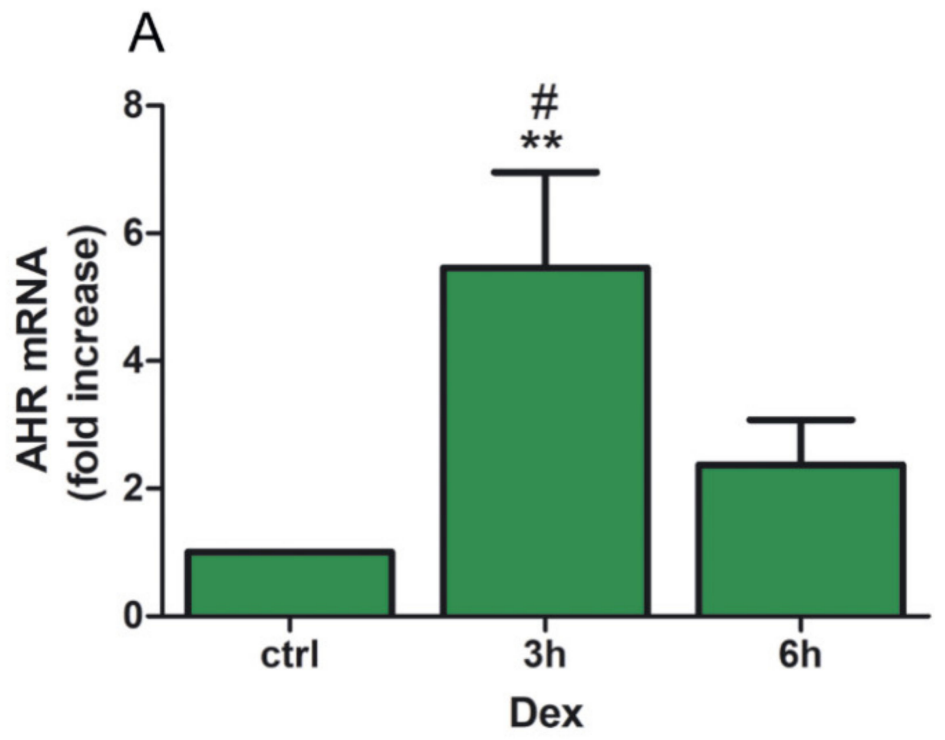

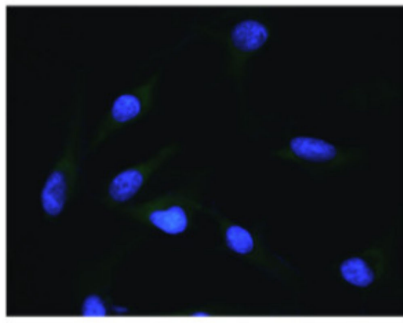

ctrl

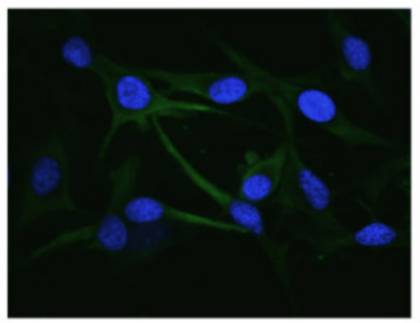

$3 \mathrm{~h}$

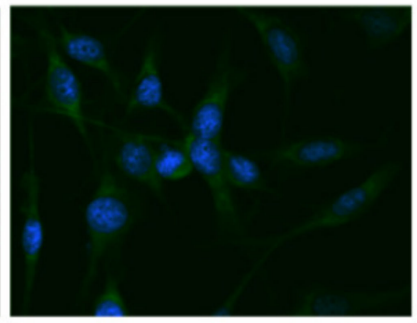

$6 \mathrm{~h}$

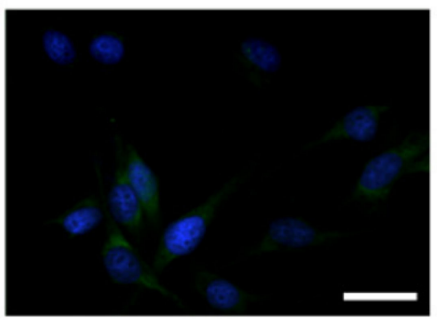

$24 \mathrm{~h}$

Figure 4. Dex modulates aryl hydrocarbon receptor (AHR) expression. (A) Cells were treated without (ctrl) or with dex $(25 \mu \mathrm{M})$ for 3 and $6 \mathrm{~h}$. Total RNA was then isolated, and real time PCR was performed. Data represent mean $\pm \mathrm{SEM},(n=5$; ${ }^{* *} p<0.001$ vs. control unstimulated (ctrl) cells; \# $p<0.05$ vs. dex 3 h. (B) Cells were treated without (ctrl) or with dex $(25 \mu \mathrm{M})$ for 3, 6, and $24 \mathrm{~h}$ followed by immunofluorescence for AHR expression (AHR: green; nuclei: blue). Representative photomicrographs at $40 \times$ magnification are shown. Scale bar $20 \mu \mathrm{m}$.

To delineate the mechanisms underlying the proliferative effect of dex, cells were pretreated for 15 min with $680 \mathrm{C} 91(40 \mu \mathrm{M})$, a selective TDO inhibitor, followed by dex $(25 \mu \mathrm{M})$. Interestingly, 680C91 significantly hampered cell proliferation by $41.2 \pm 7.1 \%$, without affecting either cell viability [24] or cell duplication in response to FGF2 (Figure 5C). Furthermore, inhibition of IDO1 with 1-MT or epacadostat, a newer IDO1 inhibitor, potentiated dex-induced cell proliferation (Figure 5D).

It is well-documented that dex activates mitogenic pathways such as the Akt and the MAPK cascades in normal [26,27] and tumor cells [21]. Here, we assessed whether dex indeed activates these pathways. Treatment with $25 \mu \mathrm{M}$ dex stimulated Akt phosphorylation within $3 \mathrm{~h}$, and this effect was partially but significantly inhibited by 680C91 (Figure 6A,B), while ERK1/2 was not activated (data not shown). The dex-activated PI3K/Akt pathway appears to mediate cell proliferation, since inhibiting this pathway did impair SK-Mel28 proliferation. Consistently, U0126, an MEK inhibitor, did not significantly alter cell proliferation (Figure 6C). 

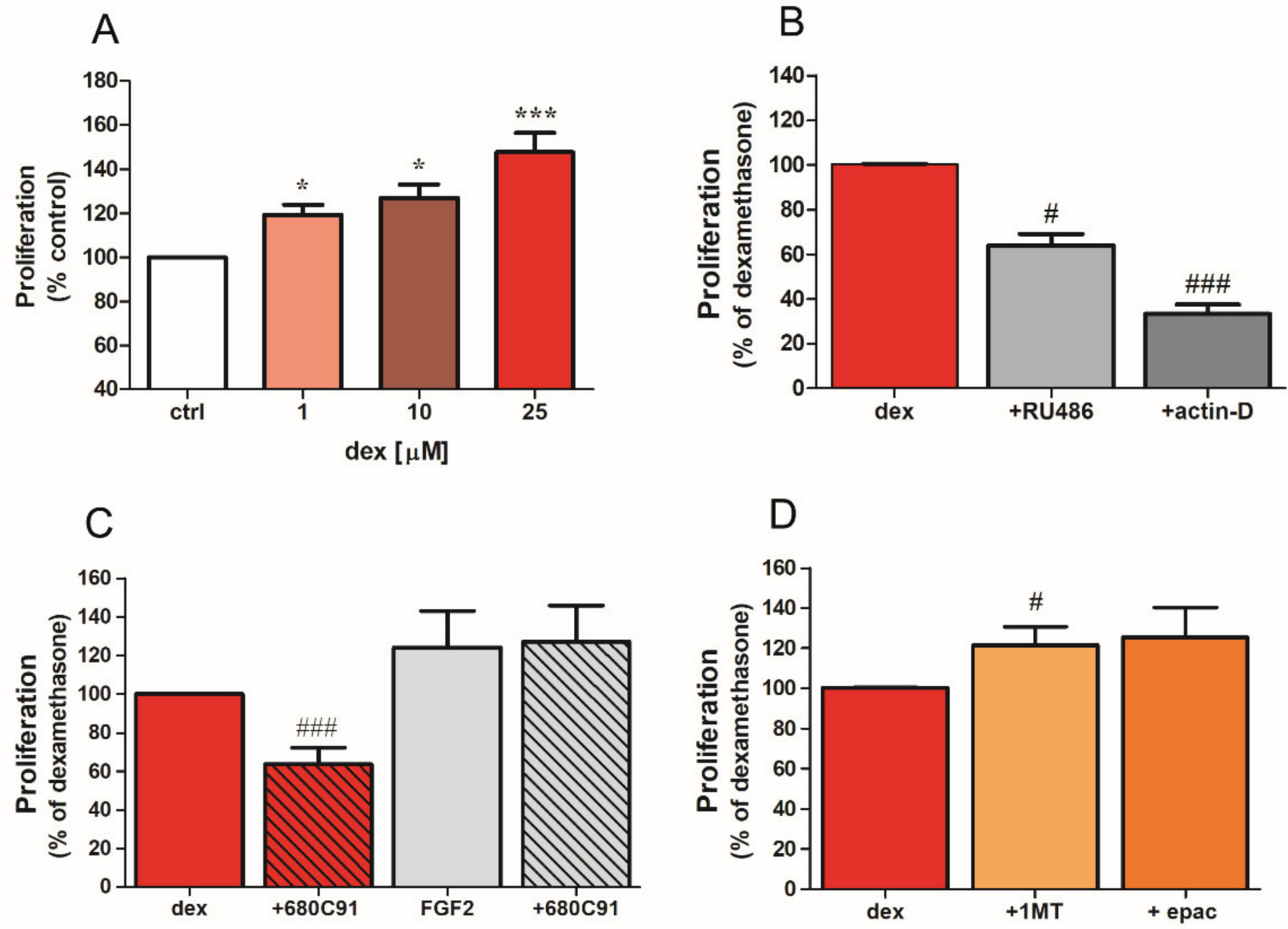

Figure 5. TDO mediates dex-induced SK-Mel-28 proliferation. (A) Cells were treated without (ctrl) or with increasing concentrations of dex for $48 \mathrm{~h}$. Data are plotted as percent of control. Mean $\pm \mathrm{SE}\left(n=7 ;{ }^{*} p<0.05\right.$, $^{* * *} p<0.001$ versus ctrl). (B-D) Cells were treated with $\operatorname{dex}(25 \mu \mathrm{M})$ alone (dex) or in presence of $(\mathbf{B})$ RU486 $(1 \mu \mathrm{M})$ or actinomycin D $(10 \mathrm{nM})$ or $(\mathbf{C})$ $680 \mathrm{C} 91(40 \mu \mathrm{M})$ and FGF2 $(10 \mathrm{ng} / \mathrm{mL})$ or $(\mathbf{D}) 1-\mathrm{MT}(40 \mu \mathrm{M})$ or epacadostat $(1 \mu \mathrm{M})$, and proliferation was assessed. Data are plotted as mean \pm SE ( $n=7 ; \# p<0.05$, \#\#\# $p<0.001$ vs. dex alone).

\subsection{Dexamethasone Stimulates SK-Mel-28 Migration}

Wound healing assay was employed to examine the effect of dex on cell migration. Our results show that, compared to control cells (1\% fetal bovine serum (FBS)), dexstimulated cells exhibited significantly higher migratory capacity (Figure 7A,B). This effect was further potentiated by epacadostat, an IDO1 inhibitor. Furthermore, dex-induced migration was mediated by its cognate receptors since pre-treatment with RU486 abolished dex-induced cell migration. Interestingly, the TDO inhibitor 680C91 delayed dex effect (Figure 7), probably due to dex-induced TDO transcription (Figure 2).

Cell chemotaxis was also assessed by means of the Boyden chamber assay. Data show that dex significantly stimulated SK-Mel-28 cell chemotaxis compared to control unstimulated cells (1\% FBS, Figure 7C,D). This effect was further potentiated by epacadostat and was impaired by RU486, actinomycin-D, and the TDO inhibitor 680C91 (Figure 7C,D). 
A

pAkt

$\beta$-tub
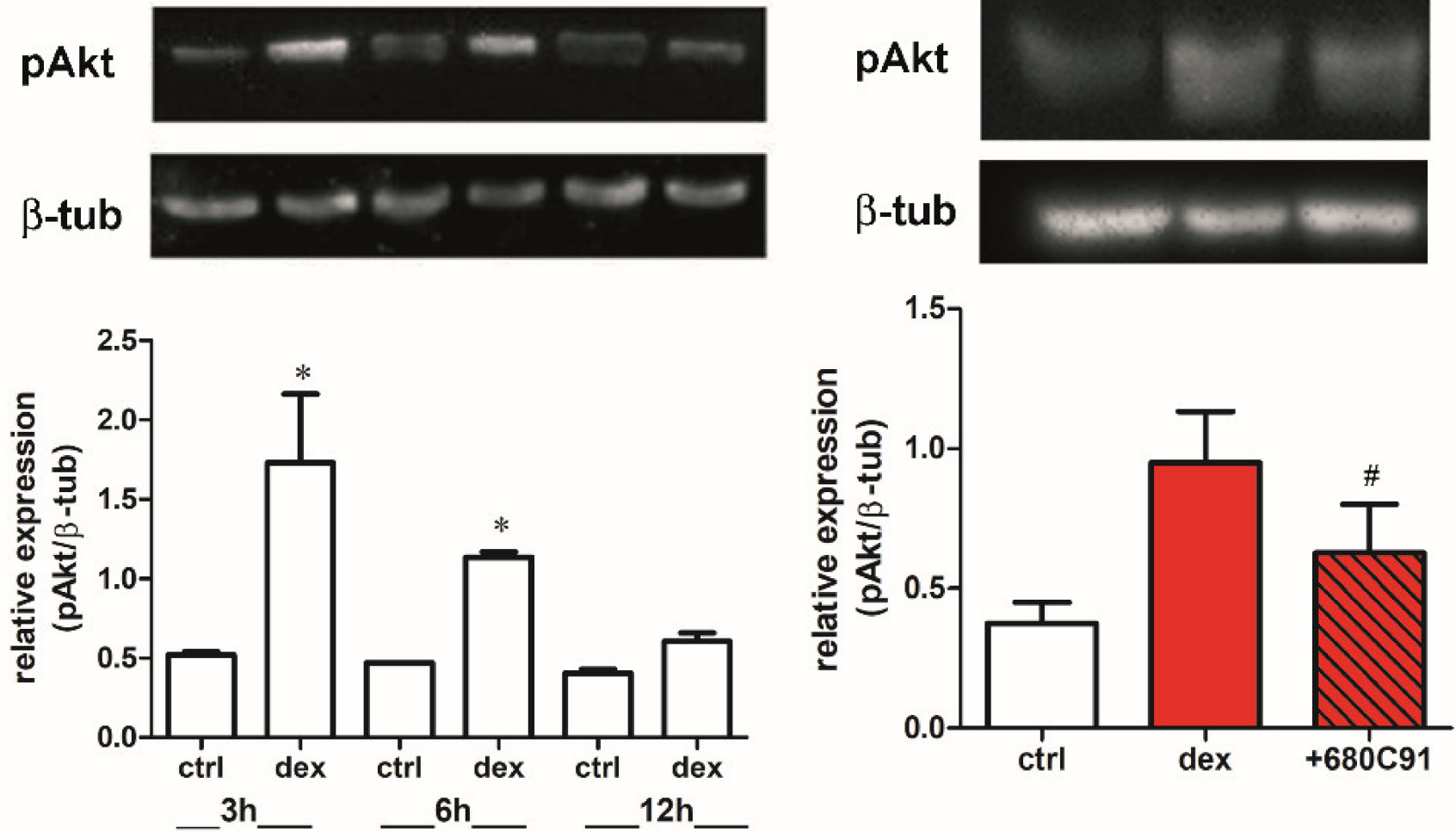

C

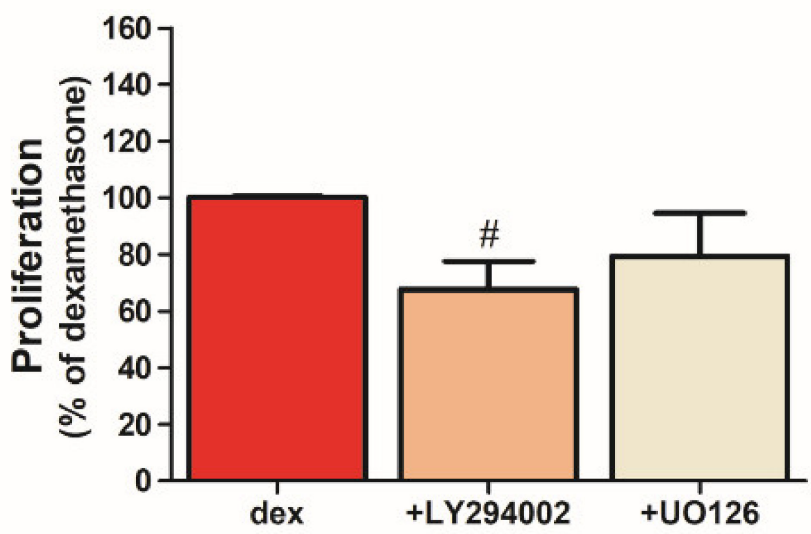

Figure 6. Dex activates Akt in SK-Mel-28 cells. (A) Cells were treated with dex for different durations (3, 6, or 12 h). Western blotting for phosphorylated Akt and $\beta$-tubulin. (B) Cells were stimulated with $25 \mu \mathrm{M}$ dex alone (dex) or in presence of $40 \mu \mathrm{M} 680 \mathrm{C} 91$ (+680C91) for $3 \mathrm{~h}\left({ }^{*} p<0.05\right.$, vs. ctrl; $\# p<0.05$ vs. dex alone). (C) Cells were treated with dex alone (dex) or co-treated with LY294002 $(5 \mu \mathrm{M})$ or U0126 $(10 \mu \mathrm{M})$, Akt and MEK inhibitors, respectively, and proliferation assessed. Data are plotted as mean $\pm \mathrm{SE}(n=3 ; \# p<0.05$, vs. dex alone). 
A

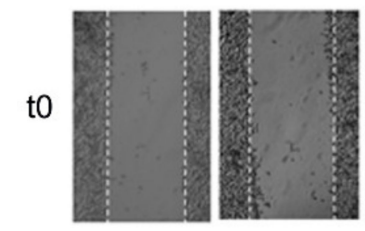

$24 \mathrm{~h}$

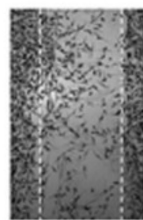

ctrl

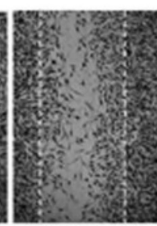

dex
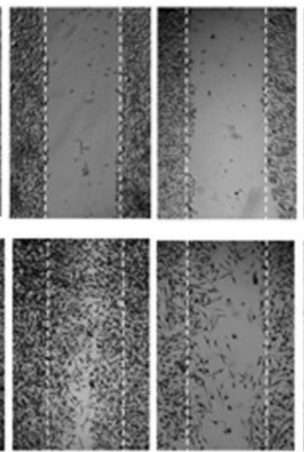

dex+epac

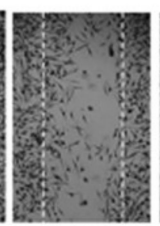

dex+RU486 dex+680C91 dex+actin-D
B

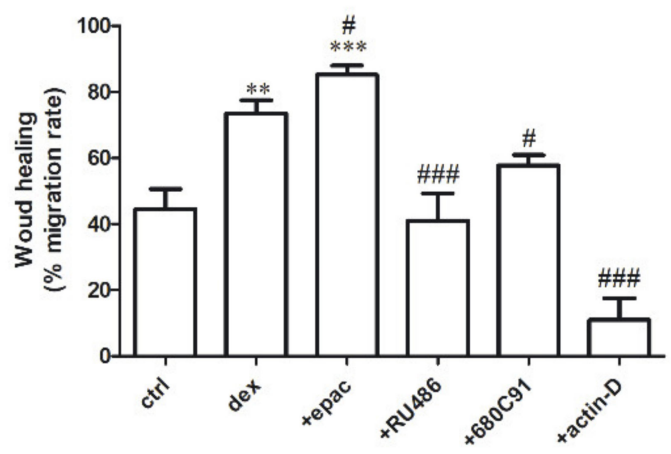

D

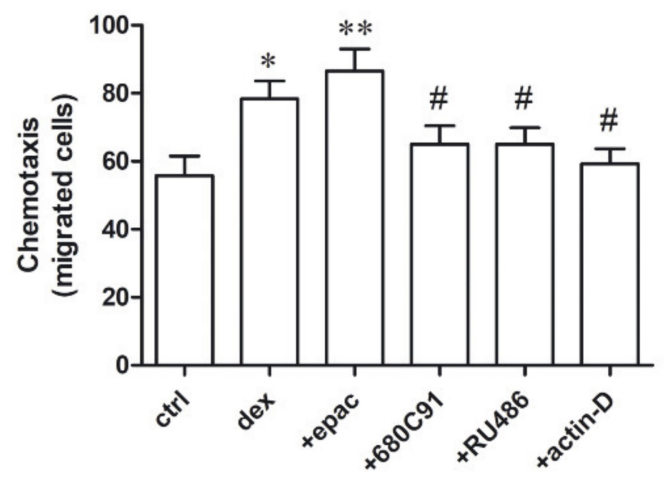

Figure 7. Dex stimulates SK-Mel-28 cell migration. (A,B) Scratched monolayer was treated with $25 \mu \mathrm{M}$ dex for $24 \mathrm{~h}$ in absence (dex) or in presence of RU486 $(1 \mu \mathrm{M}), 680 \mathrm{C} 91(40 \mu \mathrm{M})$, epacadostat $(1 \mu \mathrm{M})$, or actinomycin-D $(10 \mathrm{Nm})$. (A) Photomicrographs of the wound were taken, and representative images are shown $(4 \times)$. (B) Quantitative measure of the wound's width. Data represent mean \pm SEM of the migration rate $\left(n=5 ;{ }^{* *} p<0.01,{ }^{* * *} p<0.001\right.$ vs. control unstimulated cells (ctrl); $\# p<0.05$, \#\#\# $p<0.001$ vs. dex alone. (C,D) Chemotaxis of SK-Mel-28 cells stimulated with $25 \mu \mathrm{M}$ dex for $24 \mathrm{~h}$ in absence (dex) or in presence of RU486 $(1 \mu \mathrm{M})$, 680C91 $(40 \mu \mathrm{M})$, epacadostat $(1 \mu \mathrm{M})$ or actinomycin-D (10 nM). (C) Photomicrographs of the migrated cells were taken, and representative images are shown $(20 \times)$. (B) Quantitative measure of cell chemotaxis. Data represent mean \pm SEM of migrated cells $\left(n=4 ;{ }^{*} p<0.05,{ }^{* *} p<0.01 \mathrm{vs}\right.$. control unstimulated cells (ctrl); $\#<0.05 \mathrm{vs}$. dex alone.

\subsection{Dexamethasone Effect on MMP2 Activity}

Invasion is a hallmark of malignant phenotype of cancer cells, including melanomas. Matrix metalloproteinases (MMPs) are major drivers of cellular invasion. Among these MMPs, MMP2 seems to be the most abundantly secreted by SK-Mel-28 [28]. Thus, we measured MMP2 expression and activity in conditioned media of SK-Mel-28 cells stimulated with dex. Gelatin zymography of control supernatants showed constitutive release of the latent forms of MMP2 visualized as a band at $72 \mathrm{kDa}$ (Figure 8). Dex significantly stimulated the release of MMP2 within $48 \mathrm{~h}$ and induced its activation, revealed by the appearance of the band at $62 \mathrm{kDa}$ (Figure 8). This increase in MMP2 activity is significantly diminished by RU486 and by 680C91 (Figure 8). No effect of dex on MMP9 was observed (data not shown). 


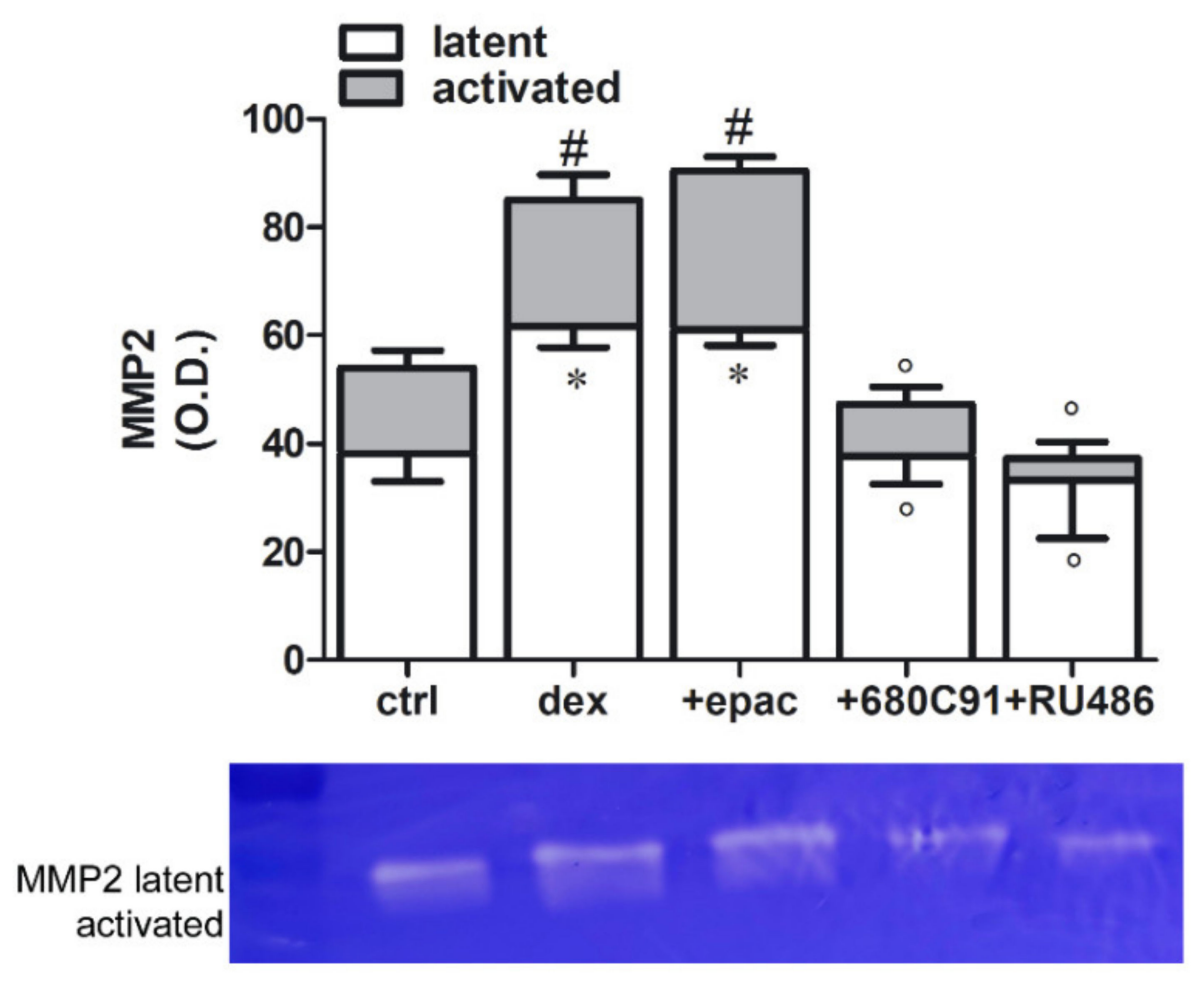

Figure 8. Gelatin zymography for matrix metalloproteinases (MMP2) production in response to dex alone or in presence of epacadostat $(1 \mu \mathrm{M})$ or $680 \mathrm{C} 91(40 \mu \mathrm{M})$ or RU486 $(1 \mu \mathrm{M})$. Results are reported as mean \pm SEM of band densitometry, $n=5 .{ }^{*} p<0.05$ vs. latent MMP2 and $\# p<0.05$ vs. activated MMP2 of control unstimulated cells (ctrl); ${ }^{\circ} p<0.05$ vs. dex alone.

\section{Discussion}

In addition to playing a key role in the KP, TDO appears to have a vital role in cancer cell's ability to evade the immune system [29]. TDO harbors GREs in its promoter, thus prompting the speculation that dex and other glucocorticoids (GCs) may regulate its expression and hence may affect tumorigenesis. Indeed, different reports highlighted a role for dex in lymphocytic malignancies as well as epithelial cell-derived cancers. In the former, dex and other GCs are routinely used to induce apoptotic cell death. Conversely, in solid tumors, GCs, mostly dex, are often used at high doses to minimize side effects of chemotherapeutic agents [19,30]. Furthermore, several reports suggest that GCs stimulate expression of anti-apoptotic genes and hence antagonize the ability of cytotoxic drugs to successfully induce cell death [31]. Moreover, in vivo studies on stress-induced GCs suggest a positive relationship between GCs and melanoma progression [32,33].

To this end, we investigated the effects of dex on both TDO expression in SK-Mel28 cells and on proliferation and migration of these cells. The present paper shows, for the first time, that dex up-regulated both mRNA and protein levels of TDO. Dex also upregulated AHR, a ligand-activated transcription factor. AHR is activated by KP metabolites, such as kynurenine, and is involved in cell proliferation, inflammation, immunity, and regulation of the melanogenic pathway [34-36]. Indeed, AHR diminishes the efficacy of novel immunotherapies by potentiation of the production of antibodies that block immunoregulatory molecules and by suppressing apoptosis of dormant melanoma cells [37]. Moreover, in triple-negative breast cancer cells, the TDO-AHR signaling axis facilitates anoikis resistance and metastasis [13] and stimulates cell migration [38].

Based on these data, it was tempting to investigate the effects of dex on SK-Mel-28 proliferation and migration in order to better assess the potential involvement of TDO in those effects. Here, we showed that dex enhanced proliferative and migratory capacities of SK-Mel-28 cells. We also showed that these effects depend on GR activation, rely on increased transcriptional activity, and are mediated by TDO. We also showed that 
dex-induced MMP2 activity is also mediated by GR and TDO. Conversely, MMP9 was undetected, in line with previous data [28]. Our results are consistent with previous reports showing that dex and prednisolone stimulate proliferation and survival of many tumor cells, both in vitro and in vivo, by activating GRs and Akt pathway [21]. Contextually, Chaudhuri et al. [39] described a detrimental effect of dex in a young patient with metastatic melanoma. This patient received dex $8 \mathrm{mg} / \mathrm{os}$ four times a day for 10 days. Although the patient symptomatically improved, it appears that the subcutaneous metastasis rapidly increased, exacerbating the disease. Moreover, metastatic nodule biopsy demonstrated a specific cytosol receptor for glucocorticoid with a $\mathrm{K}_{\mathrm{D}}$ of $1.8 \times 10^{-9} \mathrm{M}$. Other evidence confirms that glucocorticoids significantly promote adhesion, migration, invasion of melanoma cells in vitro, and lung metastasis in vivo [40]. These effects were mediated by Akt, ROCK $_{1 / 2}$, and tissue inhibitors of MMP-2 (TIMP2). In addition, dex is known to promote adhesion and survival of human and murine melanoma cell lines through fibronectin regulation and increased chemo-resistance to anticancer agents such as cisplatin [41]. Indeed, prolonged treatment of melanoma cells with dex results in the formation of a cell subline resistant to dex's growth inhibitory action by virtue of an acquired phenotype of constitutive activation of PI3K. Not surprisingly, PI3K is considered one of the key factors that regulate cell resistance to dex [42]. Dex was also reported to exhibit antiproliferative and proapoptotic effects in other cells such as HT168 and HT168-M1 cell lines [22]. These seemingly contradictory results may be explained by the fact that higher dex concentrations were used. Nonetheless, no data were indeed reported on possible TDO expression and function on HT168 and HT168-M1 melanoma cell lines. Based on our present results, it is clear that SK-Mel-28 cells physiologically express TDO whose expression and function are modulated by dex.

Since IDO1 is the principal enzyme of the KP in normal and tumor tissues, we studied its expression in SK-Mel-28 in response to dex. However, this melanoma cell line did not show IDO1 mRNA expression in control unstimulated cells, and immunofluorescence showed a faint IDO reactivity which was only upregulated in response to IFN- $\gamma$, as reported for other tumor cells [43]. However, when IDO1 was pharmacologically inhibited, dexinduced migration and proliferation were significantly increased, indicating that, in SKMel-28, the KP is driven by TDO and may be amplified when IDO1 is impaired. This may be in line with other reports [16] showing that TDO/KP could be involved in cancer biology, particularly when IDO1 does not account for the constitutive Trp catabolism.

Among the possible intracellular pathways activated by dex/TDO in SK-Mel-28, PI3K/Akt seems to be involved in dex-induced phenotypic changes. Indeed, we showed that dex stimulated Akt phosphorylation, which was critical for dex-induced proliferation. This is in line with another study which showed that T-acute lymp hoblastic leukemia (T-ALL) cells acquire resistance to dex-mediated killing through abnormal activation of Akt, resulting in inhibition of the FoxO3a/Bim pathway [44]. Furthermore, dex and prednisolone were reported to increase in vitro survival in 21/65 samples from glucocorticoid-resistant primary leukemias. Importantly, dex-induced proliferation was mediated by PI3K/AKT and p38 mitogen-activated protein kinase [21]. Moreover, dex modulated trastuzumab-induced cell growth inhibition through the restoration of trastuzumabinduced Akt suppression in BT-474 breast cancer cells [45]. All these observations suggest $\mathrm{PI} 3 \mathrm{~K} /$ Akt as the major pathway involved in pro-survival and proliferative effects of dex.

Therefore, the metastatic melanoma cell line SK-Mel-28 possesses a functional TDO which regulates SK-Mel-28 proliferation and migration in response to dex. It is well known that GCs are able to promote tumor onset and progression by virtue of their systemic immunosuppressive effects. However, GCs can have direct effects on proliferation, migration (our present data), and survival of tumor cells [21]. As shown elsewhere, GCs can also potentiate chemoresistance to therapy through regulation of genes involved in cancer progression [46,47].

Clinical evidence highlights a detrimental effect of systemic steroids during immunotherapy [48]. For instance, it was recently shown that there is an association between 
immune-related adverse events (irAEs) and outcomes in patients with stage III melanoma treated with adjuvant pembrolizumab within the KEYNOTE-054 trial [49]. Similarly, use of systemic corticosteroids during anti-PD1 nivolumab therapy was associated with poorer outcomes in non-small-cell lung cancer patients [48,50,51]. Hence, targeting glucocorticoids to increase cancer immunotherapy efficacy is an intriguing strategy. In this context, it is important to note that glucocorticoid-induced tumor necrosis factor receptor-related protein (GITR) could be an additional therapeutic target involving corticosteroid pathway. GITR is a receptor on T cells capable of inhibiting $\mathrm{T}$ cell receptor-induced apoptosis [52]; its natural ligand, GITRL, is part of the TNF superfamily, and it is expressed by a variety of cells, including mature and immature dendritic cells [52,53]. The GITR-GITRL interplay can reverse the suppression by $\mathrm{T}_{\text {reg }}$ cells while stimulating effector $\mathrm{T}$ cells [52,54]. Therefore, modulation of GITR is involved in the anti-inflammatory action of corticosteroids, making it a therapeutic target in immune regulation [52]. Preliminary results of a humanized monoclonal antibody (TRX518) that triggers GITR, given as monotherapy to patients with refractory solid tumors (including melanoma), demonstrated that TRX518 reduces circulating and intratumoral $\mathrm{T}_{\text {reg }}$ cells to a similar extent, providing an easily evaluable biomarker of anti-GITR activity [55]. More recently, an open-label, phase 1/2a study evaluated the effect of GITR-agonist IgG1 monoclonal antibody, BMS-986156, with or without nivolumab, on 292 patients with advanced solid tumors [56]. Results of this trial showed that BMS-986156 exhibits a manageable safety profile, and its combination with nivolumab is safe and efficacious, much like nivolumab monotherapy. Despite these encouraging data, further evidence in this field is still needed.

In conclusion, given the uncertain efficacy of IDO1 inhibitors together with immune checkpoint inhibitors in advanced melanoma and, based on our current results, demonstrating a direct effect of dex on TDO expression and function in human SK-Mel-28 melanoma cell line, it becomes of increasing importance to better characterize the involvement of the TDO pathway in melanoma tumorigenesis. It is also mandatory to elucidate the effects of GCs on solid tumors, including melanoma.

\section{Materials and Methods}

\subsection{Cell Culture}

SK-Mel-28 (ATCC, Manassas, VA, USA), a human metastatic melanoma cell line, was grown in high D-glucose DMEM, with $10 \%(v / v)$ heat inactivated fetal bovine serum (FBS Defined Hyclone; ThermoFisher Scientific, Waltman, Massachusetts, USA), 100 U/mL penicillin, $100 \mu \mathrm{g} / \mathrm{mL}$ streptomycin, and $2 \mathrm{mmol} / \mathrm{L}$ glutamine in a humidified atmosphere with $5 \% \mathrm{CO}_{2}$ in air. The culture medium was changed every 2 days.

\subsection{RT-PCR and Real Time PCR}

Total RNA was isolated using TRI Reagent and quantified spectroscopically with a NanoDrop (ThermoFisher Scientific). One $\mu \mathrm{g}$ of RNA was used for the reverse transcription reaction with Prime Script RT reagent Kit with gDNA eraser (Takara, Otsu, Japan), and the cDNA samples obtained were amplified with specific primers described below.

Qualitative PCR for IDO1 was performed using Wonder Taq Thermostable DNA polymerase (EuroClone, Milan, Italy). Primers for IDO1 were: fw 5'-AGTTCTGGGATGCATCACCA$3^{\prime}$ and rev 5'-TGATCGTGGATTTGGTGAAA-3'. PCR amplification comrpised 40 cycles of initial denaturation at $95{ }^{\circ} \mathrm{C}$ for $1 \mathrm{~min}$, denaturation at $95^{\circ} \mathrm{C}$ for $15 \mathrm{~s}$, annealing at $53{ }^{\circ} \mathrm{C}$ for $15 \mathrm{~s}$, and extension at $72{ }^{\circ} \mathrm{C}$ for $30 \mathrm{~s}$, followed by $5 \mathrm{~min}$ at $72{ }^{\circ} \mathrm{C}$, using 2720 Thermal Cycler Applied Biosystem (ThermoFisher Scientific). Due to undetectable cDNAs, they were concentrated combining four samples (800 ng), purified with QIAquick PCR Purification Kit (Qiagen, Hilden, Germany) according to the manufacturer instructions, and separated by $1.8 \%$ agarose electrophoresis.

Quantitative real-time PCR (qRT-PCR) was carried out using SYBR Premix Ex Taq (Takara) according to the manufacturer instructions on a Rotorgene RG-3000A cycle system (Qiagen) platform. Primer sequences were the following: TDO2 fw: 5'-CTTATCTCCAGCAT 
CAGGCTTCCAGAGT-3' and rev: 5'-GGAGTTCTTTCCAGCCATGCCTCC-3' [24], IDO1 amplification fw: $5^{\prime}$-AGTTCTGGGATGCATCACCA-3' ${ }^{\prime}$ and rev: $5^{\prime}$-CAGTTTCTTGGAGAG TTGGCA- $3^{\prime}$ and AHR amplification fw: $5^{\prime}$-CAAATCCTTCCAAGCGGCATA- $3^{\prime}$ and rev: 5'-CGCTGAGCCTAAGAACTGAAA- $3^{\prime}$.

qRT-PCR amplification of $18 \mathrm{~s}$ ribosomal mRNA was used as a normalizer. $18 \mathrm{~s}$ amplification fw: 5'-ATTAAGGGTGTGGGCCGAAG-3' and rev: 5'-GGTGATCACACGTTCCACCT-3'.

The cycle was set at $95^{\circ} \mathrm{C}$ for $5 \mathrm{~s}, 55^{\circ} \mathrm{C}$ for $30 \mathrm{~s}$, and $72{ }^{\circ} \mathrm{C}$ for $30 \mathrm{~s}$, repeated 35 times. Quantitative real-time polymerase chain reaction data analysis was accomplished with delta delta CT method.

\subsection{Cell Proliferation}

Cell proliferation was quantified by total DNA/well via a fluorescent dye (Cell proliferation kit, Invitrogen, ThermoFisher Scientific) [57]. Briefly, cells were plated on flat-bottom 96-multiwell plates and allowed to adhere overnight. Following a $24 \mathrm{~h}$ starving condition, cells were stimulated with increasing dex concentrations with or without several inhibitors: the TDO selective inhibitor, 680C91 $(40 \mu \mathrm{M})$, or the MEK inhibitor, UO126 $(10 \mu \mathrm{M})$, or the PI3K inhibitor, LY294002 $(10 \mu \mathrm{M})$. After $48 \mathrm{~h}, 50 \mu \mathrm{L}$ of dye binding solution were added to each microplate well and incubated at $37^{\circ} \mathrm{C}$ for $45 \mathrm{~min}$. Fluorescence intensity was read using a fluorescence microplate reader with excitation at $\sim 485 \mathrm{~nm}$ and emission detection at $\sim 530 \mathrm{~nm}$.

\subsection{Chemotactic Assay}

Cell migration was assessed with the modified Boyden chamber (48-multiwell plates; Neuroprobe, Gaithersburg, MD, USA) as previously reported [58]. Briefly, $1 \%$ fetal calf serum (FCS)-containing medium alone (control) or supplemented with $25 \mu \mathrm{M}$ dex was added to the lower wells, while $20 \times 10^{4}$ cells were seeded into the upper wells without or with RU486, 680C91, or actinomycin D and incubated at $37^{\circ} \mathrm{C}$ for $24 \mathrm{~h}$. Methanol-fixed cells were stained with Diff-Quik (Dade Behring, Dudingen, Switzerland), and cell migration was measured by microscopic evaluation of the number of cells moved across the filter in ten randomly selected fields at magnification $400 \times$. Each experimental point was measured in triplicate.

\subsection{Wound-Healing Assay}

Cells were cultured in 24-well plates, and after they reached 95\% confluence, a straight cell-free wound was made by manual scratching using a sterile $1000 \mu \mathrm{L}$ pipette tip. Cells were washed with PBS twice to eliminate any cellular debris, and a fresh medium was added, which served as the negative control ( $1 \% \mathrm{FBS}$, control time $0 \mathrm{~h}$ ). Cells were then stimulated with $25 \mu \mathrm{M}$ dex alone or in the presence of inhibitors. After $24 \mathrm{~h}$, cells migrated into the wounded area were visualized and photographed using an inverted light microscope. The area covered by cells was calculated with Image J (version 1.46) software, and results are reported as percent of migration rate, calculated using the formula:

Migration rate $(\%)=($ Area time $0 \mathrm{~h}-$ Area time $24 \mathrm{~h} /$ Area time $0 \mathrm{~h}) \times 100$.

\subsection{Western Blotting Analysis}

SK-Mel-28 cells were lysed in a Triton ${ }^{\circledR}$ X-100 lysis buffer, $\mathrm{pH}$ 7.4, followed by a centrifugation at $14,000 \times g \mathrm{rpm}$ for $10 \mathrm{~min}$ at $4{ }^{\circ} \mathrm{C}$ [57]. Cell lysate was run on $10 \%$ SDS-polyacrylamide gel electrophoresis, blotted onto PVDF membrane (Merck-Millipore, Darmstadt, Germany), and immunostained with anti-phospho Akt (1:1000; Cell Signaling Technology, MA, USA), anti-AHR (1:1000; Cell Signaling Technology), and anti $\beta$-tubulin monoclonal antibody (1:1000; Sigma-Aldrich, MO, USA). The antigen-antibody complexes were visualized using appropriate secondary antibodies and the ECL detection system by means of ChemiDoc imaging system (Bio-Rad Laboratories, Hercules, CA, USA) 


\subsection{Immunofluorescence}

SK-Mel-28 were seeded $\left(1 \times 10^{4}\right.$ cells $)$ in high D-glucose DMEM with $10 \%$ FBS onto LabTek Slides Chamber and incubated in a $5 \% \mathrm{CO}_{2}$ atmosphere at $37^{\circ} \mathrm{C}$ for $24 \mathrm{~h}$. Then, a fresh medium with low serum concentration ( $1 \%$ FBS) was added, and cells were stimulated with dex or IFN- $\gamma$ for 3, 6, and $24 \mathrm{~h}$. Double immunofluorescence analyses were performed on cells after fixation with cold acetone for $5 \mathrm{~min}$. Nonspecific binding sites were blocked with $10 \mathrm{mg} / \mathrm{mL}$ bovine serum albumin in PBS for $1 \mathrm{~h}$ at room temperature with $0.2 \%$ triton $\mathrm{X}-100$ (Sigma-Aldrich), then were treated with a primary antibody, i.e., monoclonal rabbit anti-human AhR (1: 100; Cell Signaling Technology), polyclonal rabbit anti-human IDO1 (1:200; abcam), or monoclonal anti human-TDO (1:200; Novus Biologicals) overnight at $4{ }^{\circ} \mathrm{C}$, then treated for $2 \mathrm{~h}$ at room temperature with a secondary goat anti-rabbit or anti-mouse antibodies conjugated with FITC AF488 (green fluorescence), all from Life Technology (Thermo Fisher Scientific). The signal was amplified with antiFITC fluorescein/Oregon green antibody for $1.5 \mathrm{~h}$ (1:100; Invitrogen) at room temperature. The nuclei were labeled with Hoechst 33,342 (20 $\mu \mathrm{g} / \mathrm{mL}$; Sigma; blue fluorescence). Omission of primary antibodies was used as negative controls. The slides were mounted with Fluoromount and examined with Leica DC200 microscope digital color camera and Leica DC Viewer software.

\subsection{Gelatin Zymography}

MMP-2 and MMP-9 activity was assessed as gel zymography [57]. Starved cells were stimulated with $25 \mu \mathrm{M}$ dex in the presence or the absence of $680 \mathrm{C} 91(40 \mu \mathrm{M})$ and epacadostat $(1 \mu \mathrm{M})$. After $24 \mathrm{~h}$, the media were collected, clarified by centrifugation at $14,000 \times g$ RPM for $7 \mathrm{~min}$, and subjected to electrophoresis onto $8 \%$ SDS-PAGE containing $1 \mathrm{mg} / \mathrm{mL}$ gelatin under non-denaturing conditions. Following electrophoresis, gels were washed with $2.5 \%$ Triton X-100 and incubated for $48 \mathrm{~h}$ at $37^{\circ} \mathrm{C}$ in a $50 \mathrm{mM}$ Tris buffer containing $200 \mathrm{mM} \mathrm{NaCl}$ and $20 \mathrm{mM} \mathrm{CaCl}_{2}$, pH 7.4. Gels were then stained with $0.5 \%$ Coomassie brilliant blue R-250 in 10\% acetic acid and $45 \%$ methanol and destained with $10 \%$ acetic acid and $45 \%$ methanol, all from Sigma-Aldrich. Gelatinase activity was then evaluated by quantitative densitometry.

\subsection{Materials}

The 680C91 ((E)-6-fluoro-3-[2-(3-pyridyl)vinyl]-1H-indole), 1-MT, a competitive inhibitor of IDO1, anti $\beta$-tubulin monoclonal antibody, TRI Reagent, and actinomycin-D were from Merck (KGaA, Darmstadt, Germany). Mouse monoclonal anti-TDO antibody was from NovusBio (Bio-Techne, Minneapolis, MI, USA). high D-glucose DMEM, and PBS were from Euroclone S.p.A. (Pero, Milan, Italy). Epacadostat was from DivBioScience, Ulvenhout, The Netherlands.

\subsection{Statistical Evaluation}

Statistical analysis was performed with Prism software (GraphPad 5.02). Parametric data were reported as means \pm SEM, and differences between groups were tested with ANOVA test (followed by Bonferroni's and Dunnett's Multiple Comparison Test) as appropriate. Alpha value was set at 0.05 .

Author Contributions: Funding acquisition, A.P.; conceptualization, A.P., M.C., S.P.; supervision, A.P., A.H.E.; experimentation, M.C., S.P., A.S.; statistical analysis: S.P., A.P. writing-original draft preparation, A.P., M.C. review and editing, A.P., A.H.E. All authors have read and agreed to the published version of the manuscript.

Funding: This work was supported by grants from University of Florence (research funding) to A.P. Institutional Review Board Statement: Not applicable.

Informed Consent Statement: Not applicable. 
Data Availability Statement: Data are available at the Dept of Health Sciences, University of Florence, Viale Pieraccini 6, 50139 Florence, Italy.

Conflicts of Interest: The authors declare no conflict of interest.

\section{References}

1. Badawy, A.A.-B. Tryptophan Metabolism: A Versatile Area Providing Multiple Targets for Pharmacological Intervention. Egypt. J. Basic Clin. Pharmacol. 2019, 9, 1-48. [CrossRef]

2. Cheong, J.E.; Sun, L. Targeting the IDO1/TDO2-KYN-AhR Pathway for Cancer Immunotherapy-Challenges and Opportunities. Trends Pharmacol. Sci. 2018, 39, 307-325. [CrossRef]

3. Brochez, L.; Chevolet, I.; Kruse, V. The rationale of indoleamine 2,3-dioxygenase inhibition for cancer therapy. Eur. J. Cancer 2017, 76, 167-182. [CrossRef] [PubMed]

4. Franklin, C.; Livingstone, E.; Roesch, A.; Schilling, B.; Schadendorf, D. Immunotherapy in melanoma: Recent advances and future directions. Eur. J. Surg. Oncol. 2017, 43, 604-611. [CrossRef]

5. Weinlich, G.; Murr, C.; Richardsen, L.; Winkler, C.; Fuchs, D. Decreased serum tryptophan concentration predicts poor prognosis in malignant melanoma patients. Dermatology 2006, 214, 8-14. [CrossRef]

6. Liu, X.; Shin, N.; Koblish, H.K.; Yang, G.; Wang, Q.; Wang, K.; Leffet, L.; Hansbury, M.J.; Thomas, B.; Rupar, M.; et al. Selective inhibition of IDO1 effectively regulates mediators of antitumor immunity. Blood 2010, 115, 3520-3530. [CrossRef]

7. Long, G.V.; Dummer, R.; Hamid, O.; Gajewski, T.F.; Caglevic, C.; Dalle, S.; Arance, A.; Carlino, M.S.; Grob, J.J.; Kim, T.M.; et al Epacadostat plus pembrolizumab versus placebo plus pembrolizumab in patients with unresectable or metastatic melanoma (ECHO-301/KEYNOTE-252): A phase 3, randomised, double-blind study. Lancet Oncol. 2019, 20, 1083-1097. [CrossRef]

8. Pilotte, L.; Larrieu, P.; Stroobant, V.; Colau, D.; Dolušić, E.; Frédérick, R.; De Plaen, E.; Uyttenhove, C.; Wouters, J.; Masereel, B.; et al. Reversal of tumoral immune resistance by inhibition of tryptophan 2,3-dioxygenase. Proc. Natl. Acad. Sci. USA 2012, 109, 2497-2502. [CrossRef]

9. Kozlova, A.; Frédérick, R. Current state on tryptophan 2,3-dioxygenase inhibitors: A patent review. Expert Opin. Ther. Pat. 2019, 29, 11-23. [CrossRef] [PubMed]

10. Britan, A.; Maffre, V.; Tone, S.; Drevet, J.R. Quantitative and spatial differences in the expression of tryptophan-metabolizing enzymes in mouse epididymis. Cell Tissue Res. 2006, 342, 301-310. [CrossRef]

11. Minatogawa, Y.; Suzuki, S.; Ando, Y.; Tone, S.; Takikawa, O. Tryptophan pyrrole ring cleavage enzymes in placenta. Adv Exp Med Biol. 2003, 527, 425-434. [PubMed]

12. Haber, R.; Bessette, D.; Hulihan-Giblin, B.; Durcan, M.J.; Goldman, D. Identification of Tryptophan 2,3-Dioxygenase RNA in Rodent Brain. J. Neurochem. 1993, 60, 1159-1162. [CrossRef]

13. D'Amato, N.C.; Rogers, T.J.; Gordon, M.A.; Greene, L.I.; Cochrane, D.R.; Spoelstra, N.S.; Nemkov, T.G.; D'alessandro, A.; Hansen, K.C.; Richer, J.K. A TDO2-AhR signaling axis facilitates anoikis resistance and metastasis in triple-negative breast cancer. Cancer Res. 2015, 75, 4651-4664. [CrossRef]

14. Opitz, C.A.; Somarribas Patterson, L.F.; Mohapatra, S.R.; Dewi, D.L.; Sadik, A.; Platten, M.; Trump, S. The therapeutic potential of targeting tryptophan catabolism in cancer. Br. J. Cancer 2020, 122, 30-44. [CrossRef]

15. Hsu, Y.L.; Hung, J.Y.; Chiang, S.Y.; Jian, S.F.; Wu, C.Y.; Lin, Y.S.; Tsai, Y.M.; Chou, S.H.; Tsai, M.J.; Kuo, P.L. Lung cancerderived galectin-1 contributes to cancer associated fibroblast-mediated cancer progression and immune suppression through TDO2/kynurenine axis. Oncotarget 2016, 7, 27584-27598. [CrossRef]

16. Opitz, C.A.; Litzenburger, U.M.; Sahm, F.; Ott, M.; Tritschler, I.; Trump, S.; Schumacher, T.; Jestaedt, L.; Schrenk, D.; Weller, M.; et al. An endogenous tumour-promoting ligand of the human aryl hydrocarbon receptor. Nature 2011, 478, 197-203. [CrossRef] [PubMed]

17. Shih, A.; Jackson, K.C. Role of corticosteroids in palliative care. J. Pain Palliat. Care Pharmacother. 2007, 21, 69-76. [CrossRef]

18. Cook, A.M.; McDonnell, A.M.; Lake, R.A.; Nowak, A.K. Dexamethasone co-medication in cancer patients undergoing chemotherapy causes substantial immunomodulatory effects with implications for chemo-immunotherapy strategies. Oncoimmunology 2016, 5, 1-11. [CrossRef] [PubMed]

19. Lin, K.T.; Wang, L.H. New dimension of glucocorticoids in cancer treatment. Steroids 2016, 111, 84-88. [CrossRef]

20. Zhang, C.; Beckermann, B.; Kallifatidis, G.; Liu, Z.; Rittgen, W.; Edler, L.; Büchler, P.; Debatin, K.M.; Büchler, M.W.; Friess, H.; et al. Corticosteroids induce chemotherapy resistance in the majority of tumour cells from bone, brain, breast, cervix, melanoma and neuroblastoma. Int. J. Oncol. 2006, 29, 1295-1301. [CrossRef]

21. Gündisch, S.; Boeckeler, E.; Behrends, U.; Amtmann, E.; Ehrhardt, H.; Jeremias, I. Glucocorticoids augment survival and proliferation of tumor cells. Anticancer Res. 2012, 32, 4251-4262.

22. Dobos, J.; Kenessey, I.; Tímár, J.; Ladányi, A. Glucocorticoid receptor expression and antiproliferative effect of dexamethasone on human melanoma cells. Pathol. Oncol. Res. 2011, 17, 729-734. [CrossRef]

23. Comings, D.E.; Muhleman, D.; Dietz, G.; Sherman, M.; Forest, G.L. Sequence of human tryptophan 2, 3-dioxygenase (TDO2): Presence of a glucocorticoid response-like element composed of a GTT repeat and an intronic CCCCT repeat. Genomics 1995, 29, 390-396. [CrossRef]

24. Paccosi, S.; Cecchi, M.; Silvano, A.; Fabbri, S.; Parenti, A. Different effects of tryptophan 2,3-dioxygenase inhibition on SK-Mel-28 and HCT-8 cancer cell lines. J. Cancer Res. Clin. Oncol. 2020, 146, 3155-3163. [CrossRef] 
25. Stejskalova, L.; Rulcova, A.; Vrzal, R.; Dvorak, Z.; Pavek, P. Dexamethasone accelerates degradation of aryl hydrocarbon receptor (AHR) and suppresses CYP1A1 induction in placental JEG-3 cell line. Toxicol. Lett. 2013, 223, 183-191. [CrossRef]

26. Cato, A.C.B.; Nestl, A.; Mink, S. Rapid actions of steroid receptors in cellular signaling pathways. Sci. STKE 2002, 2002, re9. [CrossRef]

27. Limbourg, F.P.; Liao, J.K. Nontranscriptional actions of the glucocorticoid receptor. J. Mol. Med. 2003, 81, 168-174. [CrossRef]

28. Rossi, S.; Cordella, M.; Tabolacci, C.; Nassa, G.; D’Arcangelo, D.; Senatore, C.; Pagnotto, P.; Magliozzi, R.; Salvati, A.; Weisz, A.; et al. TNF-alpha and metalloproteases as key players in melanoma cells aggressiveness. J. Exp. Clin. Cancer Res. 2018, 37, 1-17. [CrossRef]

29. Pantouris, G.; Mowat, C.G. Antitumour agents as inhibitors of tryptophan 2,3-dioxygenase. Biochem. Biophys. Res. Commun. 2014, 443, 28-31. [CrossRef] [PubMed]

30. Keith, B.D. Systematic review of the clinical effect of glucocorticoids on nonhematologic malignancy. BMC Cancer 2008, 8, 1-19. [CrossRef]

31. Zhang, C.; Wenger, T.; Mattern, J.; Ilea, S.; Frey, C.; Gutwein, P.; Altevogt, P.; Bodenmüller, W.; Gassler, N.; Schnabel, P.A.; et al. Clinical and mechanistic aspects of glucocorticoid-induced chemotherapy resistance in the majority of solid tumors. Cancer Biol. Ther. 2007, 6, 278-287. [CrossRef] [PubMed]

32. Valles, S.L.; Benlloch, M.; Rodriguez, M.L.; Mena, S.; Pellicer, J.A.; Asensi, M.; Obrador, E.; Estrela, J.M. Stress hormones promote growth of B16-F10 melanoma metastases: An interleukin 6- and glutathione-dependent mechanism. J. Transl. Med. 2013, 11, 1-14. [CrossRef] [PubMed]

33. Flaherty, D.C.; Deutsch, G.B.; Kirchoff, D.D.; Lee, J.; Huynh, K.T.; Lee, D.Y.; Foshag, L.J.; Bilchik, A.J.; Faries, M.B. Adrenalectomy for metastatic melanoma: Current role in the age of nonsurgical treatments. Am. Surg. 2015, 81, 1005-1009. [CrossRef]

34. Shimba, S.; Komiyama, K.; Moro, I.; Tezuka, M. Overexpression of the aryl hydrocarbon receptor (AhR) accelerates the cell proliferation of A549 cells. J. Biochem. 2002, 132, 795-802. [CrossRef] [PubMed]

35. Luecke, S.; Backlund, M.; Jux, B.; Esser, C.; Krutmann, J.; Rannug, A. The aryl hydrocarbon receptor (AHR), a novel regulator of human melanogenesis. Pigment Cell Melanoma Res. 2010, 23, 828-833. [CrossRef]

36. Rothhammer, V.; Quintana, F.J. The aryl hydrocarbon receptor: An environmental sensor integrating immune responses in health and disease. Nat. Rev. Immunol. 2019, 19, 184-197. [CrossRef] [PubMed]

37. Liu, Y.; Liang, X.; Yin, X.; Lv, J.; Tang, K.; Ma, J.; Ji, T.; Zhang, H.; Dong, W.; Jin, X.; et al. Blockade of IDO-kynurenine-AhR metabolic circuitry abrogates IFN- $\gamma$-induced immunologic dormancy of tumor-repopulating cells. Nat. Commun. 2017, 8, 1-15. [CrossRef]

38. Novikov, O.; Wang, Z.; Stanford, E.A.; Parks, A.J.; Ramirez-Cardenas, A.; Landesman, E.; Laklouk, I.; Sarita-Reyes, C.; Gusenleitner, D.; Li, A.; et al. An aryl hydrocarbon receptor-mediated amplification loop that enforces cell migration in ER-/PR-/Her2human breast cancer cells. Mol. Pharmacol. 2016, 90, 674-688. [CrossRef]

39. Chaudhuri, P.K.; Das Gupta, T.K.; Beattie, C.W.; Walker, M.J. Glucocorticoid-induced exacerbation of metastatic human melanoma. J. Surg. Oncol. 1982, 20, 49-52. [CrossRef]

40. Huang, G.-X.; Wang, Y.; Su, J.; Zhou, P.; Li, B.; Yin, L.-J.; Lu, J. Up-regulation of Rho-associated kinase 1/2 by glucocorticoids promotes migration, invasion and metastasis of melanoma. Cancer Lett. 2017, 410, 1-11. [CrossRef]

41. Huang, G.X.; Qi, M.F.; Li, X.L.; Tang, F.; Zhu, L. Involvement of upregulation of fibronectin in the pro-adhesive and pro-survival effects of glucocorticoid on melanoma cells. Mol. Med. Rep. 2018, 17, 3380-3387. [CrossRef]

42. Krasil'nikov, M.A.; Luzai, E.V.; Scherbakov, A.M.; Shatskaya, V.A.; Shtil, A.A.; Gershtein, E.S. Role of phosphatidylinositol-3 kinase in regulation of differential sensitivity of melanoma cells to antitumor agents. A model for hormone resistance development in tumor cells. Biochemistry 2004, 69, 322-330. [CrossRef]

43. Hennequart, M.; Pilotte, L.; Cane, S.; Hoffmann, D.; Stroobant, V.; De Plaen, E.; Van Den Eynde, B.J. Constitutive IDO1 expression in human tumors is driven by cyclooxygenase-2 and mediates intrinsic immune resistance. Cancer Immunol. Res. 2017, 5, 695-709. [CrossRef] [PubMed]

44. Xie, M.; Yang, A.; Ma, J.; Wu, M.; Xu, H.; Wu, K.; Jin, Y.; Xie, Y. Akt2 mediates glucocorticoid resistance in lymphoid malignancies through FoxO3a/Bim axis and serves as a direct target for resistance reversal. Cell Death Dis. 2018, 9, 1-16. [CrossRef] [PubMed]

45. Sumikawa, T.; Shigeoka, Y.; Igishi, T.; Suyama, H.; Yamasaki, A.; Hashimoto, K.; Matsumoto, S.; Takeda, K.; Ueda, Y.; Shimizu, E. Dexamethasone interferes with trastuzumab-induced cell growth inhibition through restoration of AKT activity in BT-474 breast cancer cells. Int. J. Oncol. 2008, 32, 683-688. [CrossRef] [PubMed]

46. Chen, Y.X.; Wang, Y.; Fu, C.C.; Diao, F.; Song, L.N.; Li, Z.-B.; Yang, R.; Lu, J. Dexamethasone enhances cell resistance to chemotherapy by increasing adhesion to extracellular matrix in human ovarian cancer cells. Endocr. Relat. Cancer 2010, 17, 39-50. [CrossRef]

47. Stringer-Reasor, E.M.; Baker, G.M.; Skor, M.N.; Kocherginsky, M.; Lengyel, E.; Fleming, G.F.; Conzen, S.D. Glucocorticoid receptor activation inhibits chemotherapy-induced cell death in high-grade serous ovarian carcinoma. Gynecol. Oncol. 2015, 138, 656-662. [CrossRef] [PubMed]

48. Indini, A.; Rijavec, E.; Grossi, F. Immune related adverse events and response to immunotherapy: Focus on corticosteroids. Lung Cancer 2020, 145, 225. [CrossRef]

49. Eggermont, A.M.M.; Kicinski, M.; Blank, C.U.; Mandala, M.; Long, G.V.; Atkinson, V.; Dalle, S.; Haydon, A.; Khattak, A.; Carlino, M.S.; et al. Association between Immune-Related Adverse Events and Recurrence-Free Survival among Patients with Stage III 
Melanoma Randomized to Receive Pembrolizumab or Placebo: A Secondary Analysis of a Randomized Clinical Trial. JAMA Oncol. 2020, 6, 519-527. [CrossRef]

50. Arbour, K.C.; Mezquita, L.; Long, N.; Rizvi, H.; Auclin, E.; Ni, A.; Martínez-Bernal, G.; Ferrara, R.; Victoria Lai, W.; Hendriks, L.E.L.; et al. Impact of baseline steroids on efficacy of programmed cell death-1 and programmed death-ligand 1 blockade in patients with non-small-cell lung cancer. J. Clin. Oncol. 2018, 36, 2872-2878. [CrossRef]

51. Scott, S.C.; Pennell, N.A. Early Use of Systemic Corticosteroids in Patients with Advanced NSCLC Treated with Nivolumab. J. Thorac. Oncol. 2018, 13, 1771-1775. [CrossRef] [PubMed]

52. Grohmann, U.; Volpi, C.; Fallarino, F.; Bozza, S.; Bianchi, R.; Vacca, C.; Orabona, C.; Belladonna, M.L.; Ayroldi, E.; Nocentini, G.; et al. Reverse signaling through GITR ligand enables dexamethasone to activate IDO in allergy. Nat. Med. 2007, 13, 579-586. [CrossRef]

53. Tone, M.; Tone, Y.; Adams, E.; Yates, S.F.; Frewin, M.R.; Cobbold, S.P.; Waldmann, H. Mouse glucocorticoid-induced tumor necrosis factor receptor ligand is costimulatory for T cells. Proc. Natl. Acad. Sci. USA 2003, 100, 15059-15064. [CrossRef] [PubMed]

54. Shimizu, J.; Yamazaki, S.; Takahashi, T.; Ishida, Y.; Sakaguchi, S. Stimulation of CD25+CD4+ regulatory T cells through GITR breaks immunological self-tolerance. Nat. Immunol. 2002, 3, 135-142. [CrossRef]

55. Zappasodi, R.; Sirard, C.; Li, Y.; Budhu, S.; Abu-Akeel, M.; Liu, C.; Yang, X.; Zhong, H.; Newman, W.; Qi, J.; et al. Rational design of anti-GITR-based combination immunotherapy. Nat. Med. 2019, 25, 759-766. [CrossRef] [PubMed]

56. Heinhuis, K.M.; Carlino, M.; Joerger, M.; Di Nicola, M.; Meniawy, T.; Rottey, S.; Moreno, V.; Gazzah, A.; Delord, J.P.; PazAres, L.; et al. Safety, Tolerability, and Potential Clinical Activity of a Glucocorticoid-Induced TNF Receptor-Related Protein Agonist Alone or in Combination with Nivolumab for Patients with Advanced Solid Tumors: A Phase 1/2a Dose-Escalation and Cohort-Expansion Clinical Trial. JAMA Oncol. 2020, 6, 100-107.

57. Paccosi, S.; Musilli, C.; Mangano, G.; Guglielmotti, A.; Parenti, A. The monocyte chemotactic protein synthesis inhibitor bindarit prevents mesangial cell proliferation and extracellular matrix remodeling. Pharmacol. Res. 2012, 66, 526-535. [CrossRef] [PubMed]

58. Cinci, L.; Luceri, C.; Bigagli, E.; Carboni, I.; Paccosi, S.; Parenti, A.; Guasti, D.; Coronnello, M. Development and characterization of an in vitro model of colorectal adenocarcinoma with MDR phenotype. Cancer Med. 2016, 5, 1279-1291. [CrossRef] 